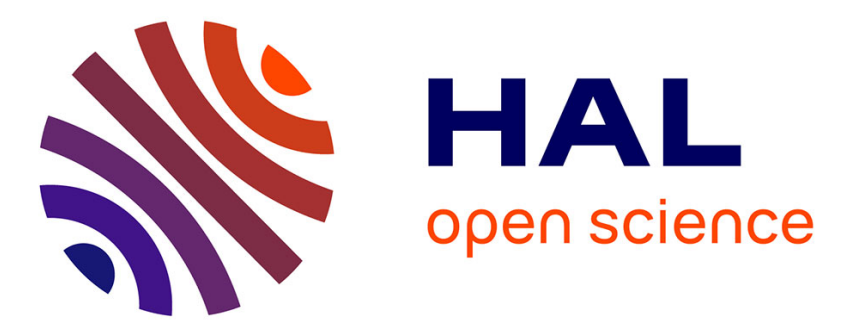

\title{
APPLICATION OF MÖSSBAUER SPECTROSCOPY TO IRON-57 IN BAUXITE RECOVERY PROCESS
}

\author{
C. Wynter, V. Hill, C. Weir, D. Radcliffe, R. Collins, F. Bramwell
}

\section{To cite this version:}

C. Wynter, V. Hill, C. Weir, D. Radcliffe, R. Collins, et al.. APPLICATION OF MÖSSBAUER SPECTROSCOPY TO IRON-57 IN BAUXITE RECOVERY PROCESS. Journal de Physique Colloques, 1979, 40 (C2), pp.C2-594-C2-595. 10.1051/jphyscol:19792207 . jpa-00218586

\section{HAL Id: jpa-00218586 https://hal.science/jpa-00218586}

Submitted on 1 Jan 1979

HAL is a multi-disciplinary open access archive for the deposit and dissemination of scientific research documents, whether they are published or not. The documents may come from teaching and research institutions in France or abroad, or from public or private research centers.
L'archive ouverte pluridisciplinaire HAL, est destinée au dépôt et à la diffusion de documents scientifiques de niveau recherche, publiés ou non, émanant des établissements d'enseignement et de recherche français ou étrangers, des laboratoires publics ou privés. 
APPLICATION OF MÖSSBAUER SPECTROSCOPY TO IRON-57 IN BAUXITE RECOVERY PROCESS

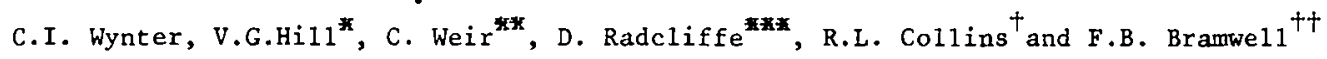

Nassau Commonity College, Garden City, N.Y. 11530, U.S.A.

* Ministry of Mining and Natural Resourees, Kingston, Jomaica

Agricultural Geology Department, University College of the West Indies, Mona, Jamaica

***ieology Dept., Hofstra University, Hempstead, N.Y., U.S.A.

+ Physics Dept, University of Texas at Austin, Austin, Texas, U.S.A.

t十 Chemistry Dept., Brooklyn College, Cuny, Brooklyn, N.Y., U.S.A.

Résumé.- Des bauxites ferrifères de la Jamaĩque, ainsi que le résidu rouge résultant du procédê d'extraction de l'alumine par la méthode de Bayer, ont été analysés par spectrométrie Mössbauer et résonance paramagnétique électronique (RPE). Il n'apparâ̂t pas de différence entre les oxydes de fer avant et après le traitement alcalin. La haute teneur en alumine des résidus rouges provient probablement d'une substitution des oxydes de fer par $\mathrm{Al}^{3+}$.

Abstract.- Mössbauer spectroscopic and electron paramagnetic resonance measurements were made on ferrugenous bauxite from Jamaica, and on the corresponding red mud residue remaining after alkaline hydrolysis treatment to extract alumina (Bayer Process). The Mössbauer parameters showed no discernable differences in the iron oxide morphologies before and after alkaline treatment. The high alumina content of the red mud residue may be explained by a substitution of trivalent aluminum in the iron oxides.

Chemical analysis of Jamaican bauxite occuring in the principal producing areas of Kirkvine, Ewarton and Alpart showed $48.5 \%, 48.8 \%$ and $47.49 \%$ alumina respectively, and the corresponding iron oxide $\left(\mathrm{Fe}_{2} \mathrm{O}_{3}\right)$ content is $18.1 \%, 19.1 \%$ and $19.4 \%$ (Table I). Similar ores are subjected to the alkaline extraction Beyer process to recover alumina. Red mud residues are a troublesome waste product.
Analyses of the residues show a surprisingly high alumina content of $13.2 \%$ in the Kirkvine red mud, $17.1 \%$ in the Ewarton and $16.0 \%$ in the Alpart residues (Table I), and this can be viewed as a serious loss of resource.

Iron oxide, the second major component in these bauxites and a principal component of red mud (Table I) can be investigated effectively by Mössbauer $/ 1,2,3 /$ and electron paramagnetic resonance.

Table I : Typical compositions of bauxite and corresponding red mud

\begin{tabular}{|c|c|c|c|c|c|c|c|c|}
\hline & $\mathrm{Al}_{2} \mathrm{O}_{3}$ & $\mathrm{Fe}_{2} \mathrm{O}_{3}$ & ${\mathrm{~S} 1 O_{2}}_{2}$ & LOI & $\mathrm{P}_{2} \mathrm{O}_{5}$ & $\mathrm{TlO}_{2}$ & $\mathrm{CaO}$ & $\mathrm{Na}_{2} \mathrm{O}$ \\
\hline \multicolumn{9}{|l|}{ Bauxite: } \\
\hline K1rkvine & 48.5 & 18.1 & 0.59 & 28.20 & 0.33 & 2.7 & .. & .. \\
\hline Ewarton & 48.8 & 19.1 & 1.84 & 27.10 & 0.28 & 2.5 & .. & . \\
\hline Alpart & 47.5 & 19.4 & 2.70 & 25.50 & 0.49 & 2.6 & 0.7 & .. \\
\hline \multicolumn{9}{|l|}{ Red Mud: } \\
\hline K1rkvine & 13.2 & 48.8 & 1.83 & .. & .. & 7.4 & 9.6 & .. \\
\hline Ewarton & 17.1 & 48.8 & 4.70 & .. & .. & 6.0 & 7.4 & .. \\
\hline Alpart & 16.0 & 42.6 & 5.90 & 12.53 & 1.00 & 5.9 & 10.3 & 3.6 \\
\hline
\end{tabular}

\footnotetext{
Kirkvine - glbbsite + hematite (typlcal plateau bauxite)

Ewarton - gibbsite + hematite + some boehmite

Alpart - gibbsite + goeth1te (themat1te) + boehmite (typical graben type)
} 
Table II : Mössbauer parameters of bauxite and red muds

\begin{tabular}{|c|c|c|c|c|c|c|c|c|c|c|c|c|c|c|c|c|}
\hline \multirow[t]{3}{*}{ Sample } & & \multicolumn{7}{|c|}{$300 \mathrm{~K}$ (room temperature) } & \multicolumn{8}{|c|}{$77 \times$ (1iquid altrogen) } \\
\hline & & Cent & $\mathrm{ral}$ D & gublet & & agnetis & Phase & & gang & tic $P$ & aase I & & Magn & $t 1 c P$ & hase II & \\
\hline & & $\begin{array}{l}\text { IS .* } \\
\mathrm{m} / \mathrm{s}\end{array}$ & $\begin{array}{l}\Delta E X \\
\Delta \mathrm{s} / \mathrm{s}\end{array}$ & $\begin{array}{l}\text { ReI. } \\
\text { Area } \\
\end{array}$ & IS: & $\Delta E_{Q}$ & $\begin{array}{l}\text { H. } \\
\text { Internal }\end{array}$ & $\begin{array}{l}\text { keI. } \\
\text { Ares }\end{array}$ & IS. & $\triangle E_{Q}$ & H. Int. & $\begin{array}{l}\text { Rel. } \\
\text { Ares }\end{array}$ & IS . & $\Delta E_{Q}$ & H. Int. & $\begin{array}{l}\text { Re1. } \\
\text { Area }\end{array}$ \\
\hline \multicolumn{2}{|l|}{ Baux 1 tes } & .34 & .49 & 52.6 & 0.370 & 0.180 & 494.2 & 47.4 & .443 & .215 & 517 & 29.4 & .537 & .027 & 470.7 & 70.6 \\
\hline \multirow[t]{3}{*}{$\begin{array}{l}\text { Red Mud } \\
\text { (residue) }\end{array}$} & A & .35 & $.46^{\circ}$ & 17.9 & 0.372 & 0.233 & 495.8 & 15.8 & .456 & .162 & 515 & 32.3 & .433 & .147 & 458.9 & 67.7 \\
\hline & B & .34 & .50 & 22.5 & 0.191 & 0.215 & 492.4 & 37.1 & .438 & .185 & 513 & 39.7 & .392 & .163 & 458.9 & 60.3 \\
\hline & c & .34 & .50 & 34.5 & 0.198 & 0.200 & 491.4 & $\beta 2.6$ & .439 & .188 & 513 & 30.8 & .368 & .482 & 452.4 & 69.2 \\
\hline
\end{tabular}

* IS. - Isomer Shift reletive to Iron

$* * \triangle E_{Q}=$ Quadrapole splitting

$\star * * \quad=$ Internal magnetic fleld

The Mössbauer parameters of the bauxites are very similar and that of three representative muds show some variations when measured at $300 \mathrm{~K}$ and $77 \mathrm{~K}$ (Table II). At $300 \mathrm{~K}$, each spectra exhibited a prominent central doublet and a magnetic phase of approximately 490 kilagauss. This internal field, which increases to about $515 \mathrm{ki}$ logauss at $77 \mathrm{~K}$, has been assigned to hematite of fine particle size and/ or substitution of diamagnetic trivalent AI in the $\alpha-\mathrm{Fe}_{2} \mathrm{O}_{3}$. This reduces the usual field strength of hematite from 515 to 490 kilogauss at room temperature $(300 \mathrm{~K})$. The paramagnetic central doublet, which results in a second magnetic phase at $77 \mathrm{~K}$ of around 460 kilogauss, has been attributed to superparamagnetism as a result of fine particles of geothite, or substitution of aluminum in geothite.
Electron paramagnetic resonance measurements were made on the same samples of bauxite and red muds at $77 \mathrm{~K}$. The spectrum of each sample indicated a principal component with a $g$ factor of 4.25 and $a$ line width at half maximum (HWHM) of 50 gauss. In addition, there is an upper field component with a $\mathrm{g}$ factor of 2.01 (HWHM $=1000$ gauss) in the bauxite but not in the red muds. It is replaced by a lower field component with a $g$ factor of 2.94 (HWHM $=$ 1000 gauss). This can be explained by a dissolution of an iron phase in the bauxite, and the production or concentration of another iron phase, which may or may not be aluminous in the red mud residues.

\section{References}

/1/ Hill, V.G. et al., Hyperfine Interactions 4 (1978) 444-447 (North-Holland Publishing Company.

/2/ Au Zaporozhets, V.M., Polosin, A.V., Kacheva, T.V. Pasova, F.G., NOV Dannye Geol. Boksitov. 2 (1975) $68-73,186-92$.

/3/ Autkacheva, T.V., Simakova, L.G., Pauker, V.I., Tsvetn. Met. (1977) 27. 